\title{
Because it's 2018: the need for early career development for female anesthesiologists
}

\author{
Robert Byrick, MD, FRCPC (1) - Douglas Craig, MD, FRCPC
}

Received: 17 September 2018/Revised: 20 September 2018/Accepted: 20 September 2018/Published online: 11 October 2018

(C) Canadian Anesthesiologists' Society 2018

In a recent letter in the Journal, Dr. Mottiar emphasized the disproportionate representation of men as recipients of honour awards from the Canadian Anesthesiologists' Society (CAS). ${ }^{1}$ She speculates that the reason for the lack of female recipients is complex; nevertheless, goes on to say that either women are not being nominated or are not selected when nominated. She suggests that the CAS should look for sources of implicit bias in the selection process. She notes that in the 20 years since women achieved parity in medical school enrolment, women in medicine are still not receiving proportional recognition or holding a major share of leadership positions.

In their response to Dr. Mottiar's analysis, Drs DuVal and McKnight, on behalf of the CAS, ${ }^{2}$ confirmed that few women are nominated and encourage more submissions in support of accomplished women working in anesthesiology in Canada.

Silver et $a{ }^{3} .^{3}$ have documented that this disproportionate under-representation of women as recognition award recipients crosses many specialty areas. Silver et al. ${ }^{3}$ also recognize that once identified, "instances of underrepresentation should then be studied with regard to causality as attempts to improve inclusion will depend on the contributing factors". As retired former Chairs of

This letter is accompanied by a reply. Please see Can J Anesth 2018; 65: this issue.

R. Byrick, MD, FRCPC ( $\square)$

Department of Anesthesia, University of Toronto, Toronto, ON,

Canada

e-mail: robert.byrick@utoronto.ca

D. Craig, MD, FRCPC

Department of Anesthesia, McGill University Health Centre,

Montreal, QC, Canada
Departments of Anesthesia, we were very involved in the development of a Canadian physician workforce planning model for the specialty of anesthesia that was published in 2000- the Ryten Report. ${ }^{4}$ This analysis was supported by the Association of Canadian University Departments of Anesthesia. An under-reported and perhaps important aspect of this analysis was the sex-related workload pattern identified.

Statistical analysis of these data was never published because the number of women in the older cohort was so low that valid statistical analysis was not possible. To quote from the Ryten report (page 98), "the differences between men and women were greatest in the youngest age groups. For example, between the ages of 30-39, on average, women worked $70 \%$ as much as men did." Workload was measured as the average number of units of clinical anesthesia service provided. Ryten found that "from age 45 onwards, the average workload of women increased ... women who remain in practice do have higher workloads than men of the same age." It appeared that over their career, the average workload was no different for men and women. The difference was that women work less during their child-rearing years and often do not get the formative experience of leadership in research, education, and administration that propel many of their male colleagues forward to successful leadership positions. Furthermore, as women return to the workforce, they tend to focus on providing clinical service, while a disproportionate number of men of the same age-having broadened their career to include leadership positions in research, education, and administration-provide less clinical service over time. We should emphasize that these data originated in 1998-99, and we are not aware of any subsequent comparable analysis; nevertheless, they 
may point to an important causative factor that is potentially remediable.

The challenge for current leaders (both male and female) is to ensure that all younger anesthesiologists gain leadership experience during early career development. This may require special consideration for women who are on maternity leave. As Dr. Mottiar emphasized, many women have made substantial contributions to our specialty, but if they are not achieving proportionate national award recognition, perhaps the selection process is not the sole problem. Rather, the need for early career development for female anesthesiologists needs to be specifically addressed.

Conflicts of interest None declared.

Editorial responsibility This submission was handled by Dr. Hilary P. Grocott, Editor-in-Chief, Canadian Journal of Anesthesia.

\section{References}

1. Mottiar M. Because it's 2018: women in Canadian anesthesiology. Can J Anesth 2018; 65: 953-4.

2. DuVal D, McKnight D. In reply to "Because it's 2018: women in Canadian anesthesiology. Can J Anesth 2018; 65: 955.

3. Silver JK, Slocum CS, Bank AM, et al. Where are the women? The underrepresentation of women physicians among recognition award recipients from medical specialty societies. PM R 2017; 9: 804-15.

4. Ryten E. A Physician Workforce Planning Model for the Specialty of Anesthesia: Theoretical and Practical Consideration (page 98). Available from URL: https://www.cas.ca/English/Page/Files/93_ Ryten\%20Report.pdf (accessed September 2018). 